\title{
EXPERIMENTÁLNE OVEROVANIE DREVENÝCH POLOTUHÝCH PRÍPOJOV S ALUMIDI KONZOLAMI
}

\author{
EXPERIMENTAL VERIFICATION OF SEMI-RIGID TIMBER \\ CONNECTIONS USING ALUMIDI CONNECTORS
}

\author{
Matúš Neusch ${ }^{*} 1$ \\ "matus.neusch@stuba.sk \\ ${ }^{1}$ STU v Bratislave, Stavebná fakulta, Katedra kovových a drevených konštrukcií, Radlinského 11, 81005 Bratislava
}

\begin{abstract}
Abstrakt
Článok sa zaoberá experimentálnym overovaním polotuhých prípojov s využitím moderných spojovacích prostriedkov Rothoblaas Alumidi. Experiment spočíva v zat’ažovaní konzoly z konštrukčného dreva. Pripravené sú 4 varianty prípoja konzoly. Každý variant bude skúšaný na 4 vzorkách. Doposial' boli overené 4 vzorky z celkového počtu 16 vzoriek. Článok opisuje prípravu experimentálnej zostavy, postup zat'ažovania, predbežné zistenia a výsledky uskutočnených experimentov. Tieto výsledky sú konfrontované s numerickými výpočtami a predpokladmi predchádzajúceho teoretického výskumu. Experimentálny výskum pokračuje skúšaním d’alších vzoriek.
\end{abstract}

\section{Klúčové slova}

Experimentálne overovanie, polotuhý prípoj, Alumidi

\begin{abstract}
This paper deals with experimental verification of semi-rigid timer connections using modern timber connectors Rothoblaas Alumidi. The experiment consists of the loading of timber bracket of structural wood. There are 4 alternatives of connection prepared. Each alternative has 4 specimens. So far, 4 specimens out of a total of 16 specimens have been verified. The paper describes the preparation of the experimental set-up, the loading procedure, the preliminary findings and the results of the performed experiments. These results are confronted with numerical calculations and assumptions of previous theoretical research. Experiment research continues with the testing of additional specimens.
\end{abstract}

Key words

Experimental verification, semi-rigid connections, Alumidi

\section{1 ÚVOD}

Ciel’om tejto práce je experimentálne overovanie výsledkov numerickej analýzy polotuhého prípoja drevenej konzoly na prievlak. Konzola z konštrukčného dreva - KVH je pripojená na preklad z lepeného lamelového dreva - LLD pomocou novodobého spájacieho prostriedku Rothotblaas Alumidi [5]. Alumidi je kovová konzola vyrobená lisovaním zo zliatiny EN AW - 6060 s hutníckym označením AlMgSi0,5. Skúmané sú Alumidi 120 a 160 bez otvorov pre hladké kolíky. KVH konzola je pripojená na Alumidi pomocou samorezných kolíkov a Alumidi konzola je pripojená na prievlak pomocou rebierkovaných klincov.

V numerickej analýze boli spočítané hodnoty modulu popustenia spojovacích prostriedkov, hodnoty rotačnej tuhosti prípojov metódou podl'a [1], [7] a deformácie KVH konzoly so zahrnutými tuhost'ami prípoja. Úlohou experimentov je vyšetrenie deformácií KVH konzoly a samotného prípoja. Z týchto údajov sú následne spätne spočítané tuhosti prípojov a charakteristiky spojovacích prostriedkov.

V tomto článku sú vyhodnotené uskutočnené experimenty, vplyv montáže prípoja, vplyv spojovacích prostriedkov a iných faktorov. Uskutočnené boli 4 vzorky z celkového počtu 16 vzoriek. Experiment bude pokračovat' skúmaním d'alších vzoriek pre overenie doterajších výsledkov. 


\section{METODIKA PRÁCE}

Prípoj je navrhnutý v 4 variantoch a každý variant bude skúšaný 4 vzorkami. Zat’ažovacia schéma je zobrazená na Obr. 1. V 1. a 2. variante je použitá konzola Alumidi 120. KVH konzola je pripojená pomocou samorezných kolíkov SBD s priemerom 7,5 mm a dížkou $75 \mathrm{~mm}$. Samotná Alumidi konzola je k prievlaku pripojená pomocou rebierkovaných klincov s priemerom $4 \mathrm{~mm}$ a dížkou $60 \mathrm{~mm}$. V 3. a 4. variante je použitá konzola Alumidi 160 - Obr. 2. Prípoj KVH konzoly sa odlišuje zvýšeným počtom samorezných kolíkov SBD a Alumidi je pripojená k prievlaku pomocou rebierkovaných klincov s dížkou $100 \mathrm{~mm}$. Schémy prípojov sú uvedené v článku [6]. Pri montáži prípoja sú dodržané konštrukčné zásady výrobcu a normové požiadavky podl'a [2] na minimálne vzdialenosti spojovacích prostriedkov.

Na Alumidi je pripojená KVH konzola dížky 750 mm z konštrukčného dreva triedy C24 a rozmermi 80/140, 80/160. Vo vzdialenosti $725 \mathrm{~mm}$ od hrany prievlaku je zo spodnej strany umiestnený hydraulický lis ENERPAC RC756. Lis je tlakovaný hydraulickou ručnou pumpou ENERPAC P-80. Medzi lis a KVH konzolu je inštalovaný snímač pôsobiacej tlakovej sily. KVH konzola je zabezpečená proti bočnej deformácii drevenou konštrukciou, ktorá nebráni zvislej deformácii.

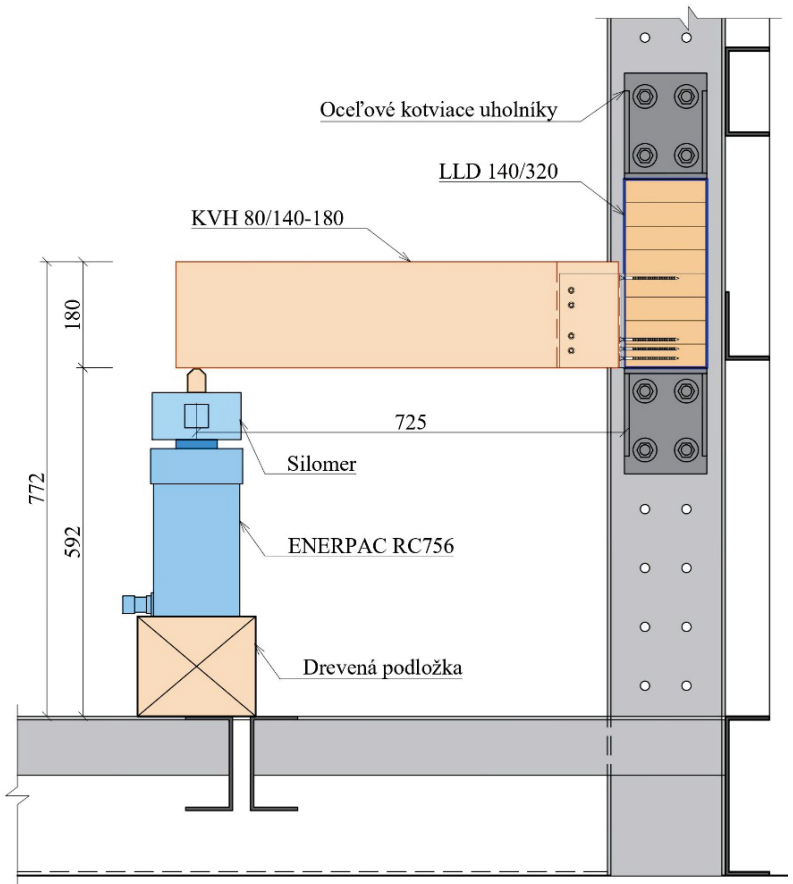

Obr. 1 Zat’ažovacia schéma.

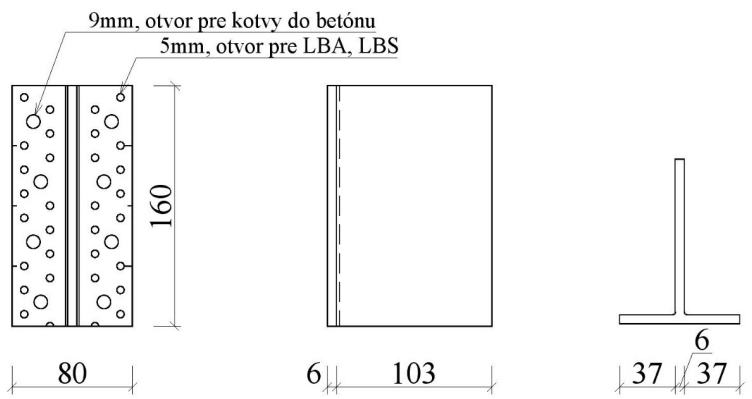

Obr. 2 Alumidi 160. 
Na vzorke sú merané deformácie KVH konzoly a deformácie Alumidi spájacieho prostriedku. Pre tento účel sú použité deformetre HBM WA-T s meratel'ným posunom $50 \mathrm{~mm}$ a $100 \mathrm{~mm}$.

Meranie prebehne v miestach:

- I1 - zvislá deformácia KVH konzoly, nezávislá od deformácie/skrútenia LLD prievlaku - HBM WA-T/100 - Obr.4,

- I2 - zvislá deformácia KVH konzoly, závislá od deformácie LLD prievlaku - HBM WA-T/100 Obr. 4,

- $\quad$ I3 - horizontálna deformácia KVH konzoly pri kolíkovom prípoji z vrchnej strany KVH, nezávislá od deformácie LLD prievlaku - HBM WA-T/50 - Obr. 4,

- I4 - horizontálna deformácia KVH konzoly pri kolíkovom prípoji z vrchnej strany KVH, závislá od deformácie LLD prievlaku - HBM WA-T/50 - Obr. 4,

- $\quad$ I5 - horizontálna deformácia KVH konzoly pri kolíkovom prípoji zo spodnej strany KVH, nezávislá od deformácie LLD prievlaku - HBM WA-T/50 - Obr. 5,

- $\quad$ I6 - horizontálna deformácia Alumidi konzoly - HBM WA-T/50 - Obr. 5.

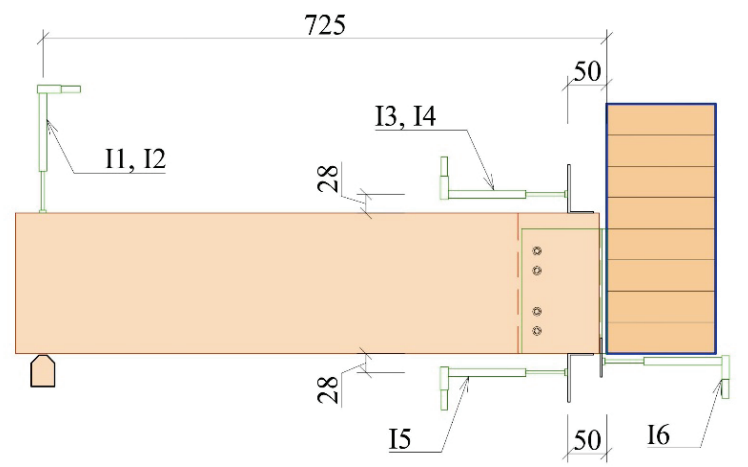

Obr. 3 Poloha deformetrov HBM WA-T.

Pri testovacom zat’ažovaní konzoly boli zistené deformácie LLD prievlaku vplyvom krútiaceho momentu. Preto boli umiestnené dva deformetre na konci konzoly - I1 a I2 a dva deformetre pri prípoji I3 a I4. Prvý z dvojice deformetrov zohl'adňuje vplyv natočenia prievlaku. Druhý z dvojice meria deformáciu od pevnej konštrukcie.

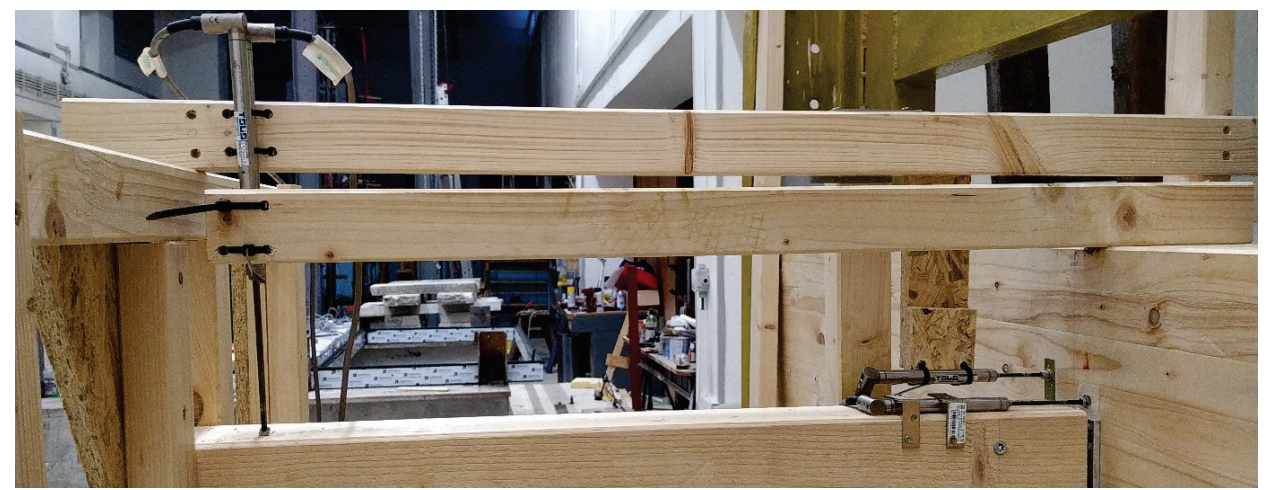

Obr. 4 Poloha deformetrov pri hornom okraji. 


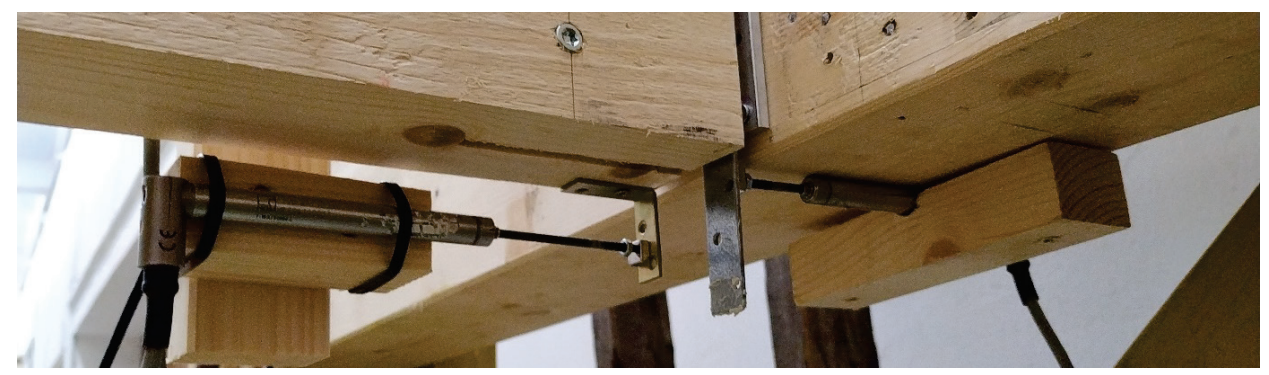

Obr. 5 Poloha deformetrov pri spodnom okraji.

Pred zat’ažovaním konštrukcie prebieha výpočet maximálnej charakteristickej sily, ktorou je možné pripravenú konštrukciu zat’ažit'. Sila je odvodená od minimálnej odolnosti kolíkového a klincového prípoja. Následne zat’aženie prebieha v 5 krokoch podl'a [3], [4]. Prvý krok je zvyšovanie sily na $40 \%$ únosnosti prípoja počas trvania 120 sekúnd. V druhom kroku konštrukcia zotrvá na tejto úrovni počas 30 sekúnd. Ďalším krokom je odl'ahčenie na úroveň $10 \%$ únosnosti. Konštrukcia na tejto úrovni zotrvá 30 sekúnd a následne prebehne zat'aženie konštrukcie na úroveň $100 \%$ charakteristickej únosnosti.

\section{VÝSLEDKY}

V tejto kapitole sú zhrnuté základné výsledky experimentálneho overovania, a to deformácie vzorky, porovnanie výsledkov s numerickou analýzou a spätný výpočet rotačnej tuhosti prípojov.

Nasledujúce grafy zobrazujú priebeh deformácií na vybraných vzorkách v čase. Z priebehu I1 a I2 je zjavné, že dochádza k pootočeniu prievlaku, čo je potrebné zahrnút' vo výpočte tuhostí prípojov.

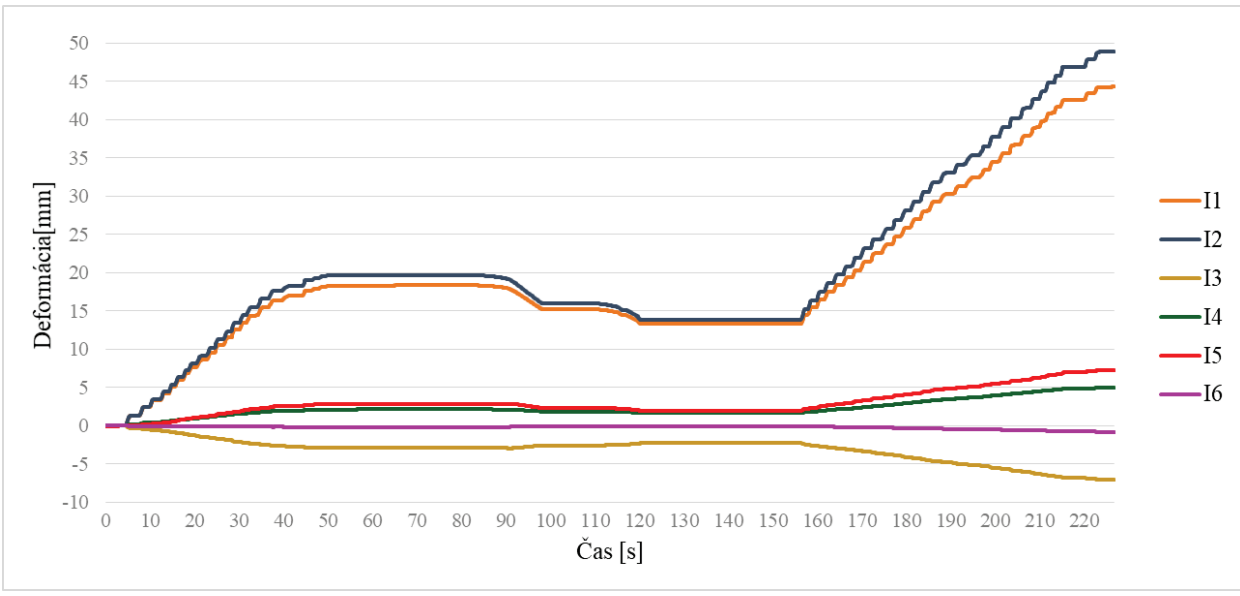

Obr. 6 Deformácie Alumidi 120 - Variant č.1, vzorka č.1. 


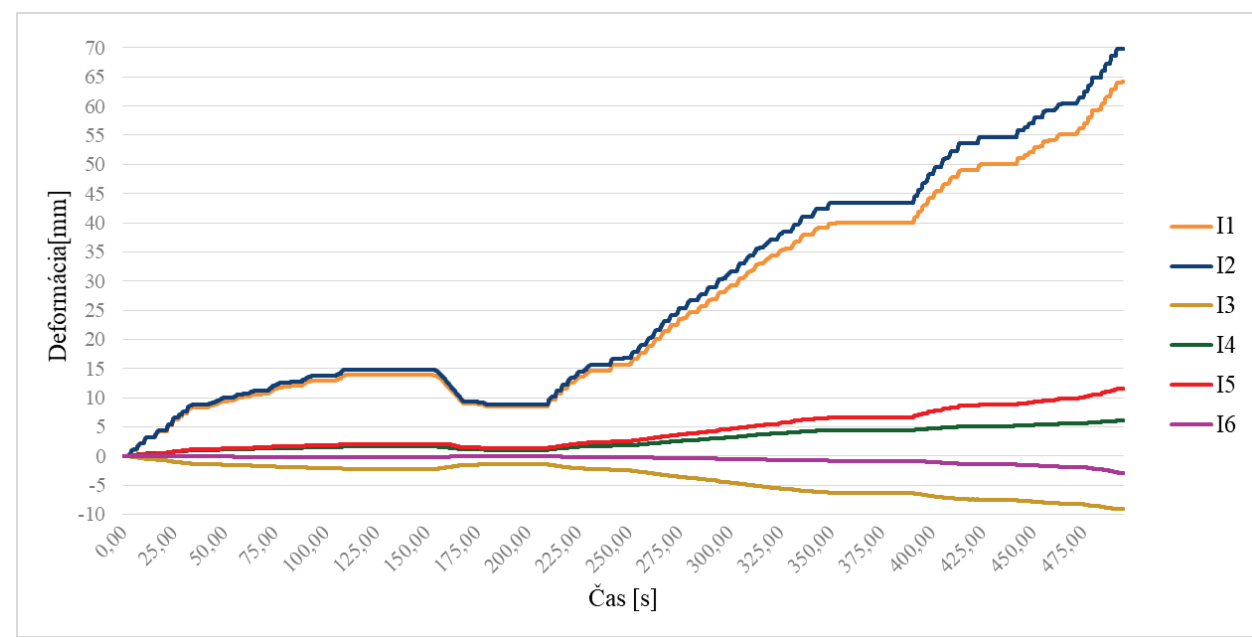

Obr. 7 Deformácie Alumidi 120 - Variant č.2, vzorka č.1.

Deformácie KVH konzoly boli vopred vypočítané pomocou 3D FE modelu v programe SCIA Engineer. Model obsahuje vypočítané rotačné tuhosti jednotlivých prípojov. V Tab. 1 sú porovnané deformácie KVH konzoly z numerickej analýzy a experimentu. Na rotačnú tuhost' a následné deformácie značne vplýva objemová tiaž dreva. Pri deformáciách je predpoklad, že s rastúcou objemovou tiažou stúpa rotačná tuhost' a klesajú deformácie. Tento predpoklad sa potvrdil pri variante 2 , avšak variant 1 ukázal opačné výsledky počas experimentu. Tento paradox je spôsobený zrejme nehomogenitami dreva a je nutné overenie d’alšími vzorkami.

Tab. 1 Vertikálne deformácie na konci KVH konzoly.

\begin{tabular}{cccccc}
\hline Variant & Vzorka & $\begin{array}{c}\text { Obj. tiaž } \\
\left(\mathbf{k g} / \mathbf{m}^{\mathbf{3}}\right)\end{array}$ & $\begin{array}{c}\text { Charak. sila } \\
(\mathbf{k N})\end{array}$ & $\begin{array}{c}\text { Def. FE model } \\
(\mathbf{m m})\end{array}$ & $\begin{array}{c}\text { Def. - experiment } \\
(\mathbf{m m})\end{array}$ \\
\hline \multirow{2}{*}{1} & 1 & 457 & 1,38 & 24,5 & 48,8 \\
& 2 & 362 & 1,38 & 32,1 & 43,4 \\
2 & 1 & 490 & 1,63 & 22,2 & 43,3 \\
& 2 & 550 & 1,75 & 20,8 & 37,7 \\
\hline
\end{tabular}

Tab. 2 Rotačná tuhost' klincového prípoja - Alumidi 120.

\begin{tabular}{cccc}
\hline Variant & Vzorka & $\begin{array}{c}\text { Výpočtová tuhost' } \\
\mathbf{C}_{\boldsymbol{\psi}, \text { num }} \\
(\mathbf{M N m} / \mathbf{r a d})\end{array}$ & $\begin{array}{c}\text { Tuhost' z experimentu } \\
\mathbf{C}_{\boldsymbol{\psi}, \text { exp }} \\
(\mathbf{M N m} / \mathbf{r a d})\end{array}$ \\
\hline \multirow{2}{*}{1} & 1 & 0,1375 & 0,1734 \\
& 2 & 0,1375 & 0,1549 \\
2 & 1 & 0,2238 & 0,2379 \\
& 2 & 0,2238 & 0,2256 \\
\hline
\end{tabular}

Tab. 3 Rotačná tuhost' kolíkového prípoja - Alumidi 120.

\begin{tabular}{ccccc}
\hline Variant & Vzorka & $\begin{array}{c}\text { Obj. tiaž } \\
\left(\mathbf{k g} / \mathbf{m}^{\mathbf{3}}\right)\end{array}$ & $\begin{array}{c}\text { Výpočtová tuhost' } \\
\mathbf{C}_{\boldsymbol{\psi}, \text { num }} \\
(\mathbf{M N m} / \mathbf{r a d})\end{array}$ & $\begin{array}{c}\text { Tuhost' z experimentu } \\
\mathbf{C}_{\boldsymbol{\psi}, \boldsymbol{e x p}} \\
(\mathbf{M N m} / \mathbf{r a d})\end{array}$ \\
\hline \multirow{2}{*}{1} & 1 & 457 & 0,0313 & 0,0137 \\
& 2 & 362 & 0,0220 & 0,0147 \\
2 & 1 & 490 & 0,0396 & 0,0210 \\
& 2 & 550 & 0,0471 & 0,0242 \\
\hline
\end{tabular}


V Tab. 2 sú zobrazené rotačné tuhosti klincovej časti prípoja. Z výsledkov je zrejmé, že predpoklady v numerickej analýze sú správne. Vo variante č. 1 je väčšia tuhost' z experimentu daná nehomogenitami dreva, a to konkrétne rastovými hrčami v mieste prípoja Alumidi na prievlak.

Tab. 3 zobrazuje výsledky tuhostí kolíkovej časti prípoja. Rovnako ako pri deformáciách, aj tu sa prejavil vplyv materiálových imperfekcií, a to konkrétne pri variante 1 a vzorke 2, ktorá má väčšiu tuhost' ako vzorka $1 \mathrm{~s}$ vyššou objemovou tiažou. Celkovo sú hodnoty tuhostí z experimentu výrazne nižšie, čo je zrejme spôsobené geometriou a spôsobom aplikácie samorezných kolíkov.

\section{DISKUSIA}

Počas montáže vzoriek a v priebehu experimentu boli zistené viaceré faktory, ktoré výrazne vplývajú na výsledky. Jedným z prvých zistení bol spôsob vítania samorezných kolíkov a ich geometria. Výrobca nepredpisuje predvŕtanie kolíkov, avšak pri takejto aplikácii dochádzalo k vôli v prípoji a konštrukcia nadobudla počiatočnú deformáciu bez pôsobenia zat’aženia. Tento problém bol vyriešený predvítaním kolíkov vrtákom s priemerom $5 \mathrm{~mm}$. Predvŕtaná bola drevená čast' a rovnako aj konzola Alumidi.

Počas zat’ǎovania boli zistené nadmerné deformácie KVH konzoly. Tieto deformácie boli spôsobené zatláčaním vítacieho hrotu samorezného kolíka do dreva. V tejto časti je kolík výrazne sploštený a má nedostatočný driek. V prípade nepriaznivého natočenia kolíka v dreve dochádza k zatláčaniu hrotu do dreva.

Maximálna charakteristická sila, ktorou je možné konštrukciu zat'ažit' bola vypočítaná pre každú vzorku zvlášt' na základe rozdielnej objemovej tiaže jednotlivých vzoriek. Pre presnejšie výsledky je nutné vzorky z jedného variantu zat'ažit' rovnakou charakteristickou silou. Rovnako je potrebné dodržat' časy pri zat'ažovaní vzoriek.

Na výsledky má zjavný vplyv aj nehomogenita dreva, a to konkrétne výsušné trhliny, suky a iné. Na základe numerickej analýzy bolo očakávané krehké porušenie kolíkového prípoja. Všetky spomenuté vplyvy však spôsobili duktilné správanie a na konštrukcii nedošlo ku krehkému porušeniu.

\section{ZÁVER}

Experimentálne boli overené prvé 4 vzorky polotuhého prípoja KVH konzoly na LLD prievlak pomocou novodobého spájacieho prostriedku Alumidi. Počas experimentu boli merané deformácie KVH konzoly a samotného konektora Alumidi. Výsledky experimentu boli použité pri spätnom výpočte rotačnej tuhosti prípojov a iných pevnostných charakteristík. Následne boli tieto výsledky porovnané s numerickou analýzou prípojov.

Polotuhé pôsobenie prípojov v drevených konštrukciách lepšie opisuje správanie novodobých spojovacích prostriedkov a ich vplyv na návrh drevenej nosnej konštrukcie.

Pre potvrdenie výsledkov a väčší štatistický súbor bude experimentálne overených d’alších 12 vzoriek.

\section{Pod'akovanie}

Rád by som sa pod'akoval spoločnostiam ROTHO BLAAS SRL, WHC Slovakia s.r.o. a INGSTEEL, spol. s.r.o. za poskytnuté spojovacie prostriedky a materiál pre účely experimentu.

\section{Použité zdroje}

[1] Schickhofer, G. 2006. Holzbau Nachweisführen für Konstruktionen aus Holz (Graz: Institut für Holzbau \& Holztechnologie Technische Universität Graz)

[2] STN EN 1995-1-1 + A1: Eurocode 5 - Design of timber structures - Part 1-1: General - Common rules and rules for buildings. SÚTN, 2008

[3] STN EN 383: Drevené konštrukcie. Skúšobné metódy. Stanovenie pevnosti stien otvorov a charakteristík stačitel'nosti pre kolíkové spájacie prostriedky. SÚTN, 2007

[4] STN EN 380: Drevené konštrukcie. Skúšobné metódy. Všeobecné zásady skúšania statickým zat’ažením, SÚTN, 1998

[5] Rothoblaas katalóg, dostupný dňa 25.11.2021

[6] Neusch, M. 2020. Experimental verification of semi-rigid timber connections using Alumidi connectors. In Juniorstav 2020 : proceedings, Brno : VUT, 2020. ISBN: 978-80-86433-73-8, s. 334-339.

[7] Gečys, T., \& Daniūnas, A. (2017). Rotational stiffness determination of the semi-rigid timber-steel connection. Journal of Civil Engineering and Management, 23(8), 1021-1028.

https://doi.org/10.3846/13923730.2017.1374305 